Document downloaded from:

http://hdl.handle.net/10251/120695

This paper must be cited as:

Fernández Domene, RM.; Sánchez Tovar, R.; Lucas-Granados, B.; Muñoz-Portero, M.; Ramírez-Grau, R.; Garcia-Anton, J. (2018). Visible-light photoelectrodegradation of diuron on WO3 nanostructures. Journal of Environmental Management. 226:249-255. https://doi.org/10.1016/j.jenvman.2018.08.044

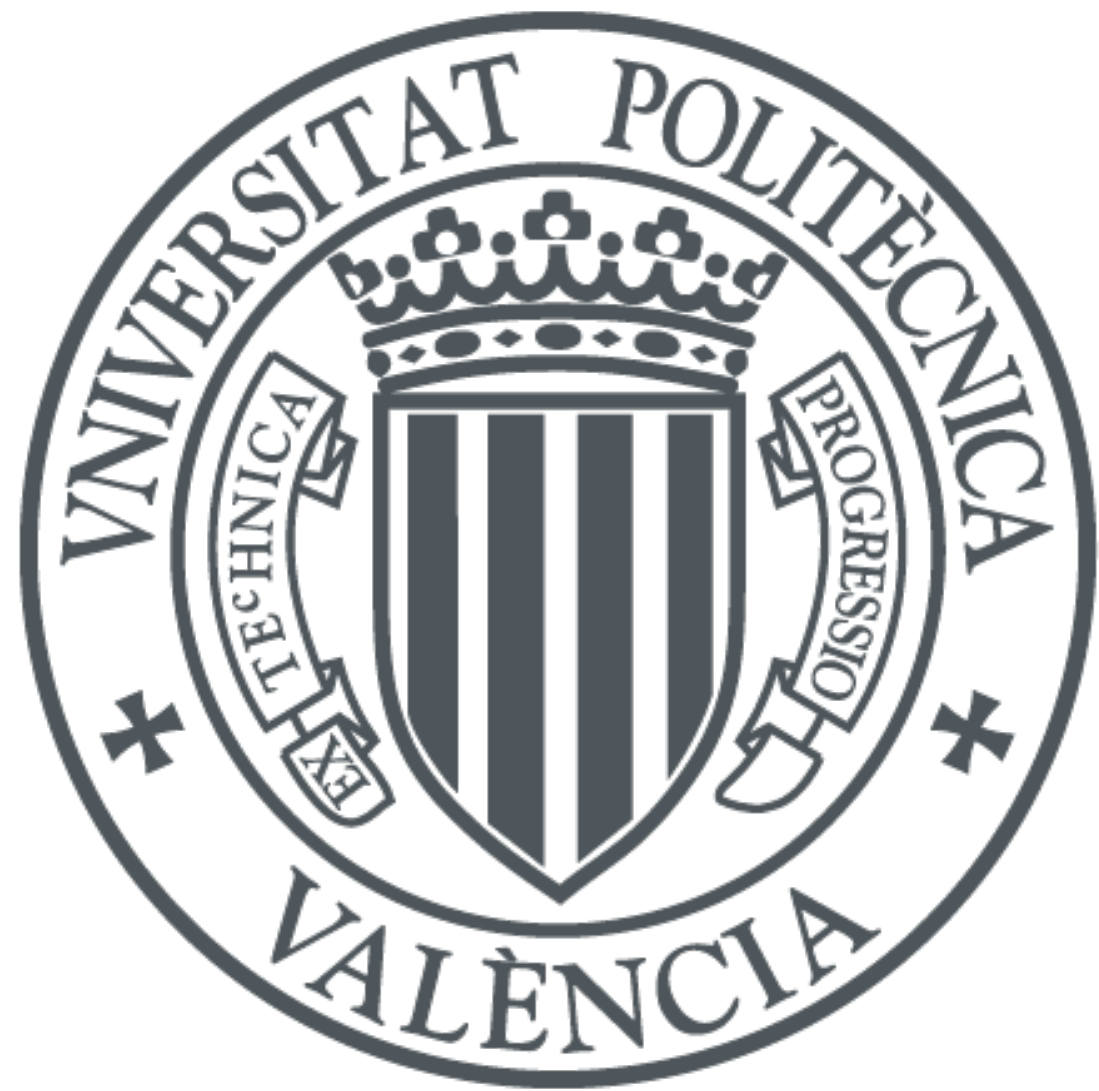

The final publication is available at

http://doi.org/10.1016/j.jenvman.2018.08.044

Copyright Elsevier

Additional Information 


\title{
VISIBLE-LIGHT PHOTOELECTRODEGRADATION OF DIURON ON WO3 NANOSTRUCTURES
}

\author{
Fernández-Domene, R.M.; Sánchez-Tovar, R.; Lucas-Granados, B.; Muñoz- \\ Portero, M.J.; Ramírez-Grau, R.; García-Antón, J.* \\ Ingeniería Electroquímica y Corrosión (IEC). Departamento de Ingeniería Química y \\ Nuclear. ETSI Industriales. Universitat Politècnica de València. Camino de Vera s/n, \\ 46022 Valencia, Spain. Tel. 34-96-387 76 32, Fax. 34-96-387 76 39, \\ *e-mail: jgarciaa@iqn.upv.es (J.García-Antón).
}

The degradation of pesticide diuron has been explored by photoelectrocatalysis (PEC) under visible light illumination using two different $\mathrm{WO}_{3}$ nanostructures, obtained by anodization of tungsten. The highest degradation efficiency (73\%) was obtained for $\mathrm{WO}_{3}$ nanosheets synthesized in the presence of small amounts of hydrogen peroxide $(0.05 \mathrm{M})$. For that nanostructure, the kinetic coefficient for diuron degradation was $133 \%$ higher than that for the other nanostructure (anodized in the presence of fluoride anions). These results have been explained by taking into account the different architecture and dimensions of the two $\mathrm{WO}_{3}$ nanostructures under study.

KEYWORDS: Photoelectrocatalysis; $\mathrm{WO}_{3}$ nanostructures; anodization; diuron; pesticides. 


\section{INTRODUCTION}

Photoelectrocatalysis (PEC) is an advanced oxidation process which has been investigated as an efficient method for the removal of recalcitrant organic molecules from wastewaters [1-4]. PEC is a multidisciplinary field, involving electrochemistry, materials science, solid-state physics and optics [3]. When light of enough energy reaches the surface of a semiconductor, electrons from the valence band are excited to the conduction band, leaving a positive-charged hole behind, hence creating photogenerated charge carriers, i.e., electron-hole pairs $\left(\mathrm{e}^{-}-\mathrm{h}^{+}\right)$. Unlike simple photocatalysis (PC), in PEC a small potential is applied to the photocatalyst (n-type semiconductor) to minimize the recombination of the photogenerated charge carriers (see scheme in Figure 1). This external polarization increases the semiconductor band bending and sustains the electric field inside the space-charge region, thus favoring the transport of electrons from the semiconductor conduction band to the counter electrode and increasing the lifetime of holes [2]. Valence-band holes oxidize the aqueous medium to generate hydroxyl radicals, which are extremely oxidant species and can react with the recalcitrant organic molecules ( $\mathrm{R}$ in Figure 1). Additional and more complex configurations for PEC cells can be found in the literature [5-8].

Nanostructured semiconductors are ideal for PEC, since their high surface area facilitates the interaction between the semiconductor surface and the electrolyte, creating many active sites where photogenerated holes can react with water molecules to generate hydroxyl radicals. Besides, charge transfer and light absorption are highly enhanced by using nanostructures $[3,9]$. Among the semiconductor oxides investigated for PEC applications, $\mathrm{WO}_{3}$ nanostructures present interesting properties, such as band 
gap values around $2.6 \mathrm{eV}(\lambda=477 \mathrm{~nm})$ that permit the absorption of visible light and high chemical and photoelectrochemical resistance in acidic environments $[1,10]$. $\mathrm{WO}_{3}$ photoanodes have been synthesized to degrade organic compounds such us dyes [1121], pesticides [22] or drugs and other chemicals [23-27].

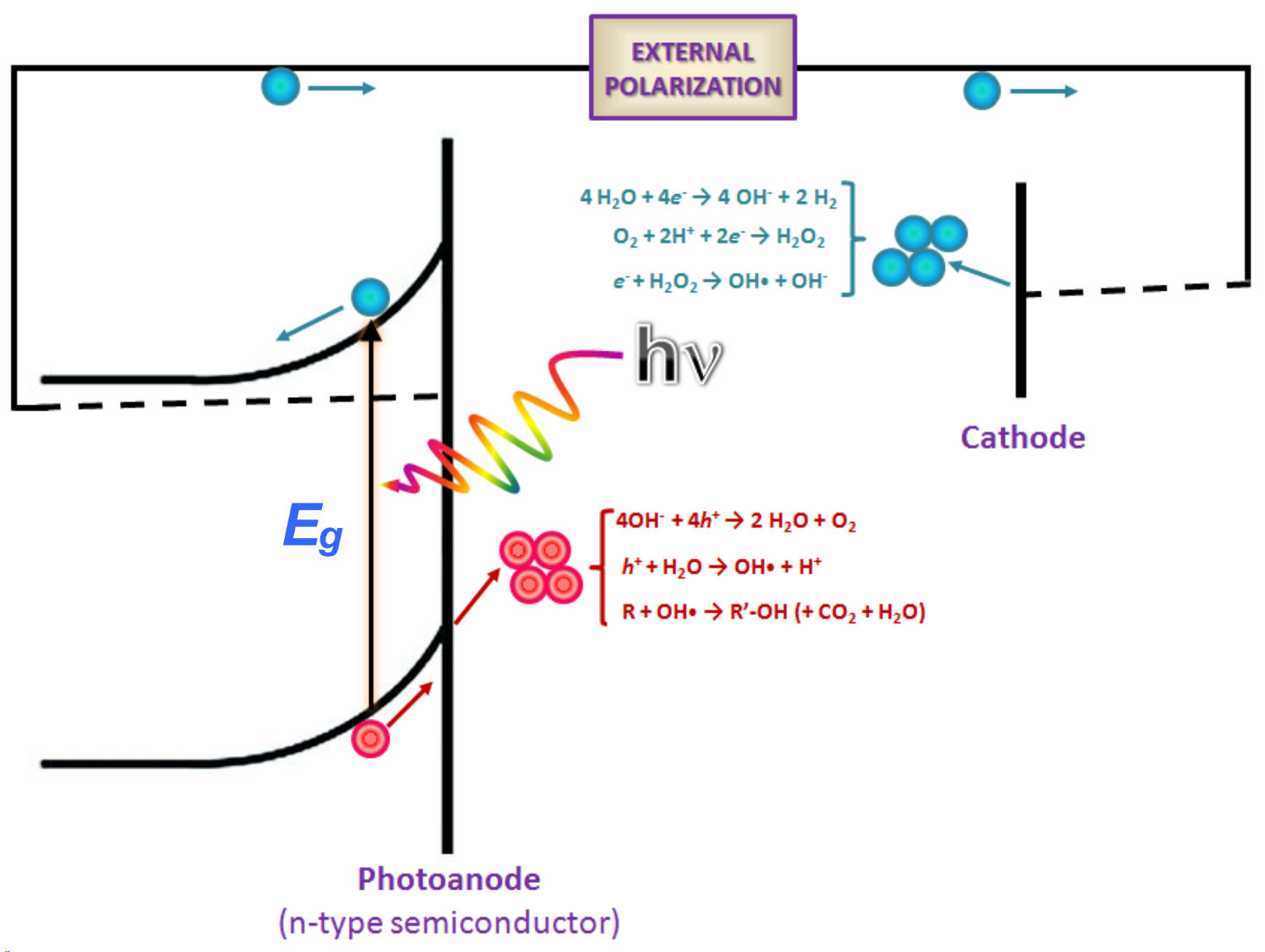

Figure 1. Scheme of a photoelectrocatalytic cell.

This work studies the PEC degradation of diuron (Figure 2), a persistent herbicide, by using high-performance $\mathrm{WO}_{3}$ nanostructures. Diuron (3-(3,4-dichlorophenyl)-1,1dimethylurea) is an inhibitor of photosynthesis broadly used in both crop and non-crop areas. It is a substance very toxic to aquatic life and it is suspected of causing cancer and damage to organs through prolonged or repeated exposure [28-36]. Diuron is persistent, mobile and has been found in surface and groundwater [29, 37-49]. In this work, an 
effective and feasible PEC method for diuron elimination from wastewaters is presented for the first time.

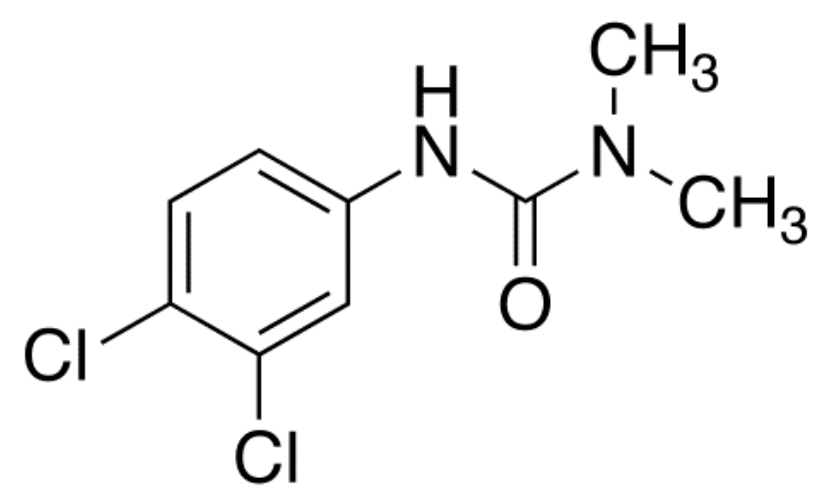

Figure 2. Diuron molecule.

\section{MATERIALS AND METHODS}

Aqueous solutions of diuron were prepared from analytical standard grade diuron supplied by Sigma-Aldrich $\left(\right.$ Pestanal $\left.^{\circledR}\right)$. Solutions were prepared with distilled water and stirring for $24 \mathrm{~h}$ in the dark.

$\mathrm{WO}_{3}$ photoanodes were prepared by electrochemical anodization of tungsten rods ( 8 $\mathrm{mm}$ in diameter) immersed in two different electrolytes: $1.5 \mathrm{M} \mathrm{H}_{2} \mathrm{SO}_{4}+0.1 \mathrm{M} \mathrm{NaF}$ and $1.5 \mathrm{M} \mathrm{H}_{2} \mathrm{SO}_{4}+0.05 \mathrm{M} \mathrm{H}_{2} \mathrm{O}_{2}$, both at $50^{\circ} \mathrm{C}$. Tungsten rods were covered with a Teflon coating to prevent the rest of the surface from contacting the electrolyte $\left(0.5 \mathrm{~cm}^{2}\right.$ of surface exposed to the solution). The cell potential difference between the tungsten working electrode and a platinum mesh counter electrode was set at $20 \mathrm{~V}$ for $4 \mathrm{~h}$, and the tungsten electrode was continuously rotated at $375 \mathrm{rpm}$ by using a rotating disk electrode (RDE), according to a previous work [50]. After anodization, samples were annealed in a tubular furnace at $400^{\circ} \mathrm{C}$ for $4 \mathrm{~h}$ in an air atmosphere. 
$\mathrm{WO}_{3}$ nanostructures were morphologically characterized by using a Field Emission Scanning Electron Microscopy (FESEM).

PEC performance of the $\mathrm{WO}_{3}$ nanostructures was evaluated by degrading a $20 \mathrm{mg} \mathrm{L}^{-1}$ diuron solution with $0.1 \mathrm{M} \mathrm{H}_{2} \mathrm{SO}_{4}$ as a supporting electrolyte, under $420 \mathrm{~nm}$ light (by using a $1000 \mathrm{~W}$ Xe light source, $100 \mathrm{~mW} \mathrm{~cm}^{-2}$ at $420 \mathrm{~nm}$ ) and applying an external potential of $1 \mathrm{~V}$. The acidic supporting electrolyte was used to enhance the photoelectrocatalytic performance of nanostructures, according to a previous work [21]. The reactor was a quartz glass cell with three electrodes: the $\mathrm{WO}_{3}$ nanostructure was the working electrode $\left(0.5 \mathrm{~cm}^{2}\right.$ exposed to the diuron solution), an $\mathrm{Ag} / \mathrm{AgCl}(3 \mathrm{M} \mathrm{KCl})$ was the reference electrode and a Pt tip was the counter electrode. In total, $14 \mathrm{ml}$ of the diuron solution were added to the reactor. Prior to the degradation tests, samples were immersed in the diuron solution for 30 minutes at their open circuit potential to achieve initial equilibrium conditions. Photocurrent density values were recorded during the whole tests.

At regular time intervals of the reaction (every 30 minutes), $4 \mathrm{~mL}$ of the diuron solution were taken and analyzed immediately by UV-visible spectrophotometry, measuring the absorbance between $190 \mathrm{~nm}$ and $300 \mathrm{~nm}$. After that, the aliquot was returned to the reactor to continue with the process. The extent of the degradation reaction was also quantified by measuring the concentration of chloride and nitrate anions resulting from the decomposition of the diuron molecule (see Figure 2). This measure was performed with a Metrohm 883 Basic IC plus ion chromatograph equipped with a Metrosep A Supp 5- (150/4 mm) separation column. The eluent was a carbonate/bicarbonate (3.2/1 $\mathrm{mM}$ ) buffer solution at a flow rate of $0.7 \mathrm{~mL} \mathrm{~min}^{-1}$ and the suppressor was a $0.1 \mathrm{M}$ 
$\mathrm{H}_{2} \mathrm{SO}_{4}$ solution. Under these experimental conditions, retention times for both anions were $\sim 6 \min$ for $\mathrm{Cl}^{-}$and $\sim 10.3 \min$ for $\mathrm{NO}_{3}{ }^{-}$.

\section{RESULTS AND DISCUSSION}

\subsection{Nanostructures morphology: influence of anodization electrolyte}

The results of the morphological FESEM analysis of the $\mathrm{WO}_{3}$ nanostructures are presented in Figure 3. The most characteristic feature of the nanostructure fabricated in the NaF electrolyte was the formation of ordered nanoplatelets arranged in 3D globular clusters (Figure 3a). The length of these nanoplatelets was determined to be $626 \pm 25$ $\mathrm{nm}$, their width $29.2 \pm 1.2 \mathrm{~nm}$, and the thickness of the whole nanoplatelet layer $15.5 \pm$ $1.5 \mu \mathrm{m}$. When synthesized in the presence of $\mathrm{H}_{2} \mathrm{O}_{2}$ (instead of $\mathrm{NaF}$ ), a morphological change in the nanostructures was observed (Figure 3b). In that case, the size of formed nanostructures was greatly reduced. Indeed, minuscule nanoplatelets/nanosheets were formed, and they no longer aggregated forming spherical clusters, but forming layers whose thickness was determined to be $2.1 \pm 0.3 \mu \mathrm{m}$. The reduced dimensions of these nanosheets might contribute to increase the electrochemically active area, hence resulting in higher electrocatalytic activities of the photoanodes [9].

The differences in shape and size observed for the two synthesized $\mathrm{WO}_{3}$ nanostructures can be explained by taking into account the interaction between tungsten species and the complexing agent present in the anodization electrolyte $\left(\mathrm{F}^{-}\right.$or $\left.\mathrm{H}_{2} \mathrm{O}_{2}\right)$. In order to analyze the formation mechanism of both nanostructures, current density transients obtained during anodization are presented in Figure 3c. Both $i$ vs $t$ curves present common features. At the beginning of the process, current densities abruptly decreased due to the 
formation of a compact $\mathrm{WO}_{3}$ layer as a consequence of substrate oxidation, regardless of the used electrolyte. After a short time, current densities started increasing in both cases due to the dissolution of the previously formed $\mathrm{WO}_{3}$ layer by the action of $\mathrm{F}^{-}$and $\mathrm{H}_{2} \mathrm{O}_{2}$. Soluble complex tungsten species were formed, according to:

$$
\begin{aligned}
& \mathrm{WO}_{3}+6 \mathrm{H}^{+}+\mathrm{nF}^{-} \rightarrow\left[\mathrm{WF}_{\mathrm{n}}\right]^{(6-\mathrm{n})}+3 \mathrm{H}_{2} \mathrm{O} \\
& 2 \mathrm{WO}_{3}+4 \mathrm{H}_{2} \mathrm{O}_{2} \rightarrow\left[\mathrm{W}_{2} \mathrm{O}_{11}\right]^{2-}+2 \mathrm{H}^{+}+3 \mathrm{H}_{2} \mathrm{O}
\end{aligned}
$$

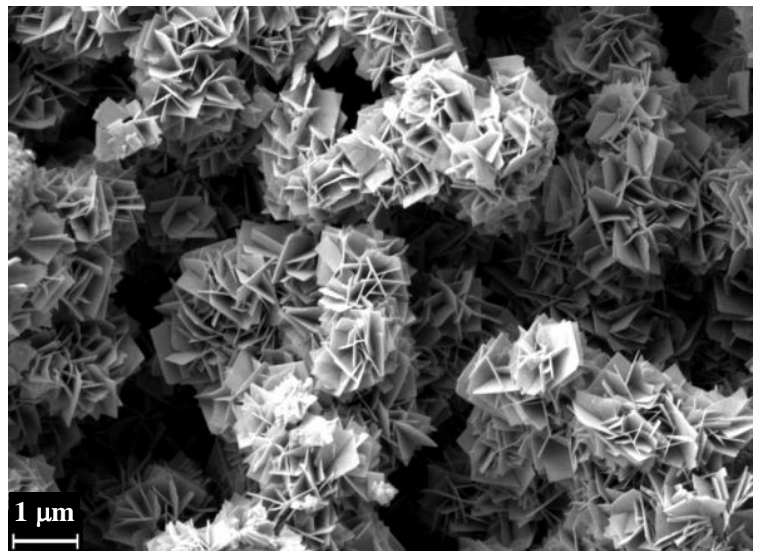

(a)

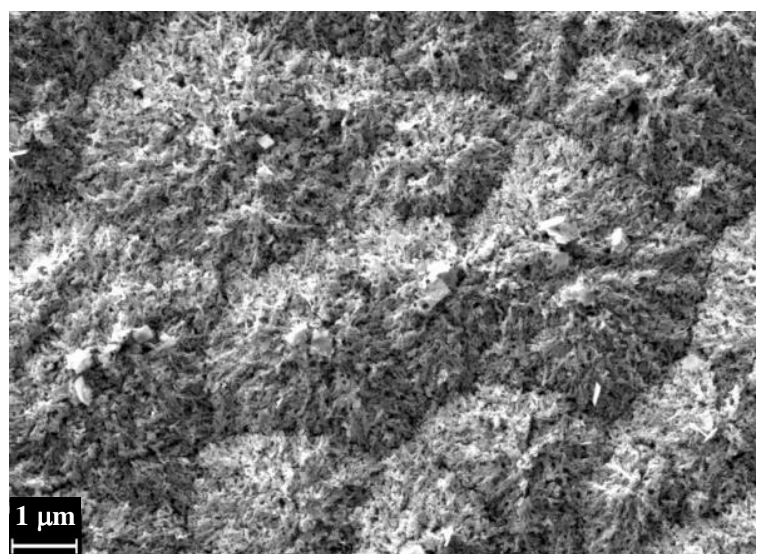

(b

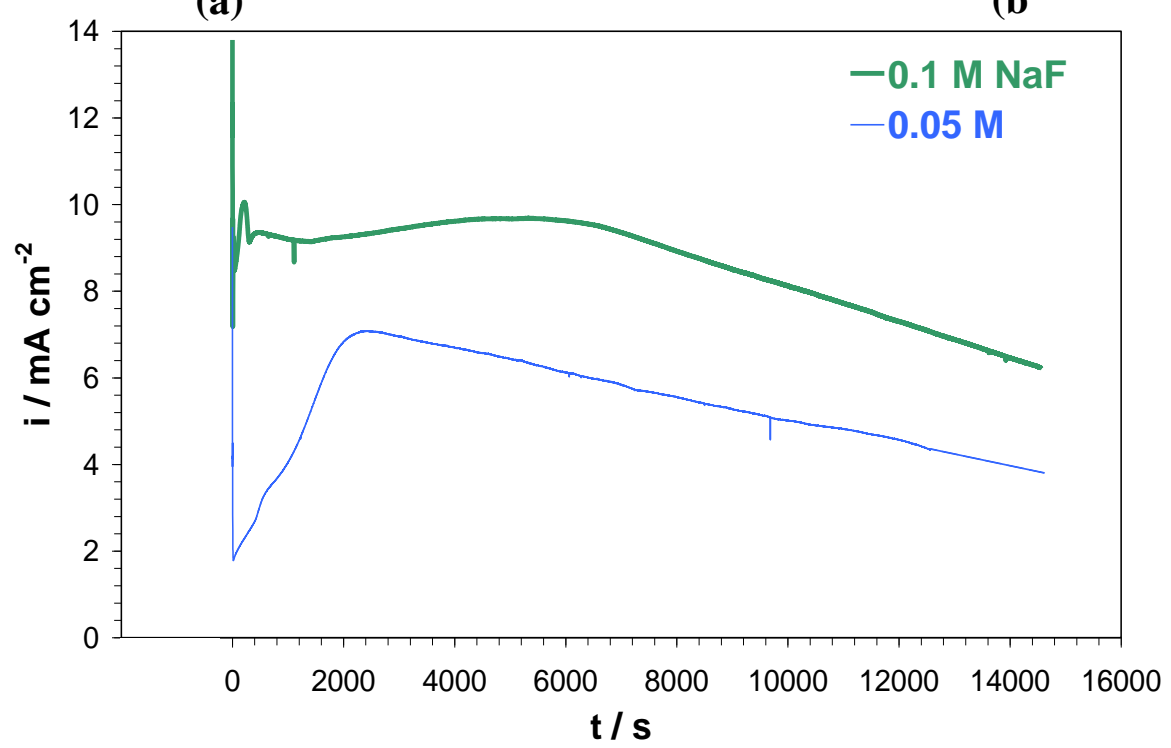

(c)

Figure 3. FESEM images of the $\mathrm{WO}_{3}$ nanostructures synthesized in the $1.5 \mathrm{M} \mathrm{H}_{2} \mathrm{SO}_{4}+$ $0.1 \mathrm{M} \mathrm{NaF}$ electrolyte (a) and in the $1.5 \mathrm{M} \mathrm{H}_{2} \mathrm{SO}_{4}+0.05 \mathrm{M} \mathrm{H}_{2} \mathrm{O}_{2}$ electrolyte (b); current density transients obtained during anodization for both $\mathrm{WO}_{3}$ nanostructures (c). 
In both curves, a decrease in current density was also observed after reaching a maximum value. This decrease is directly related to the precipitation of soluble complex tungsten species formed by reactions (1) and (2) once supersaturation conditions were reached near the electrode surface. This process, characteristic of tungsten compounds, is known as polycondensation $[50,51]$ and resulted in the formation of the $\mathrm{WO}_{3}$ nanostructures shown above (Figure 3a and Figure 3b). Details on the formation mechanism briefly summarized above can be found in a previous study [50].

Nevertheless, there are also visible differences in the curves presented in Figure 3c. First, current densities were higher in the NaF electrolyte, which can be explained by the higher concentration of fluorides with respect to $\mathrm{H}_{2} \mathrm{O}_{2}\left(0.1 \mathrm{M} \mathrm{NaF}\right.$ vs $\left.0.05 \mathrm{M} \mathrm{H}_{2} \mathrm{O}_{2}\right)$. Second, the time at which current density started decreasing (after reaching a maximum value) was shorter in the case of the peroxide-containing solution $(\sim 2400 \mathrm{~s})$ than in the $\mathrm{F}^{-}$solution ( 6400 s) (Figure 3c). Finally, the slope of the region of decreasing current densities (precipitation of soluble tungsten species) was higher, in absolute value, for the sample fabricated in the $\mathrm{NaF}$ solution. Hence, the precipitation of $\mathrm{WO}_{3}$ nanostructures in the $0.05 \mathrm{M} \mathrm{H}_{2} \mathrm{O}_{2}$ electrolyte started at shorter times than in the $0.1 \mathrm{M}$ $\mathrm{NaF}$ electrolyte, but their rate of formation was slower than in the $\mathrm{F}^{-}$-containing solution. These facts may explain the morphological and dimensional differences between the two $\mathrm{WO}_{3}$ nanostructures depicted in Figures 3a and 3b, i.e, nanostructures fabricated in the presence of $\mathrm{F}^{-}$grew faster than in the presence of $\mathrm{H}_{2} \mathrm{O}_{2}$, and hence their distribution was less compact (3D growing) and their size was higher than layer-ordered nanosheets formed in the peroxide-containing solution.

\subsection{Photoelectrocatalytic degradation of diuron}


Photocurrent densities $\left(i_{p h}\right)$ were recorded during the whole degradation experiments and the mean values obtained every 30 min are presented in Figure 4 for the two $\mathrm{WO}_{3}$ nanostructures used in this work. Photocurrent densities were always significantly higher for the nanostructures synthesized in the $0.05 \mathrm{M} \mathrm{H}_{2} \mathrm{O}_{2}$ electrolyte. Photocurrent density values obtained in PEC systems have two main contributions: one coming from the electrocatalytic process and other arising from the photon absorption process. The electrocatalytic process consumes the photogenerated charge carriers and it can become the rate-determining step of the PEC process (the charge transfer at the semiconductor/electrolyte interface) [9]. Current densities in electrochemistry are directly influenced by the real surface active area, since increasing surface area enhances the number of electroactive sites; therefore, from $i_{p h}$ results in Figure 4, it can be said that nanosheets obtained in the presence of hydrogen peroxide had a higher electrocatalytic activity than nanoplatelets formed in the $\mathrm{F}^{-}$-containing electrolyte. Moreover, in the nanostructure formed in the $0.05 \mathrm{M} \mathrm{H}_{2} \mathrm{O}_{2}$ solution, the very small size of nanosheets and their distribution forming layers, instead of tree-like globular clusters, may result in a reduction of photogenerated holes diffusion path towards the semiconductor/electrolyte interface and may also improve electron movement towards the metallic back contact. Hence, electron-hole recombination would be reduced for nanosheets formed in the peroxide-containing solution and the overall efficiency of the PEC would be enhanced. 


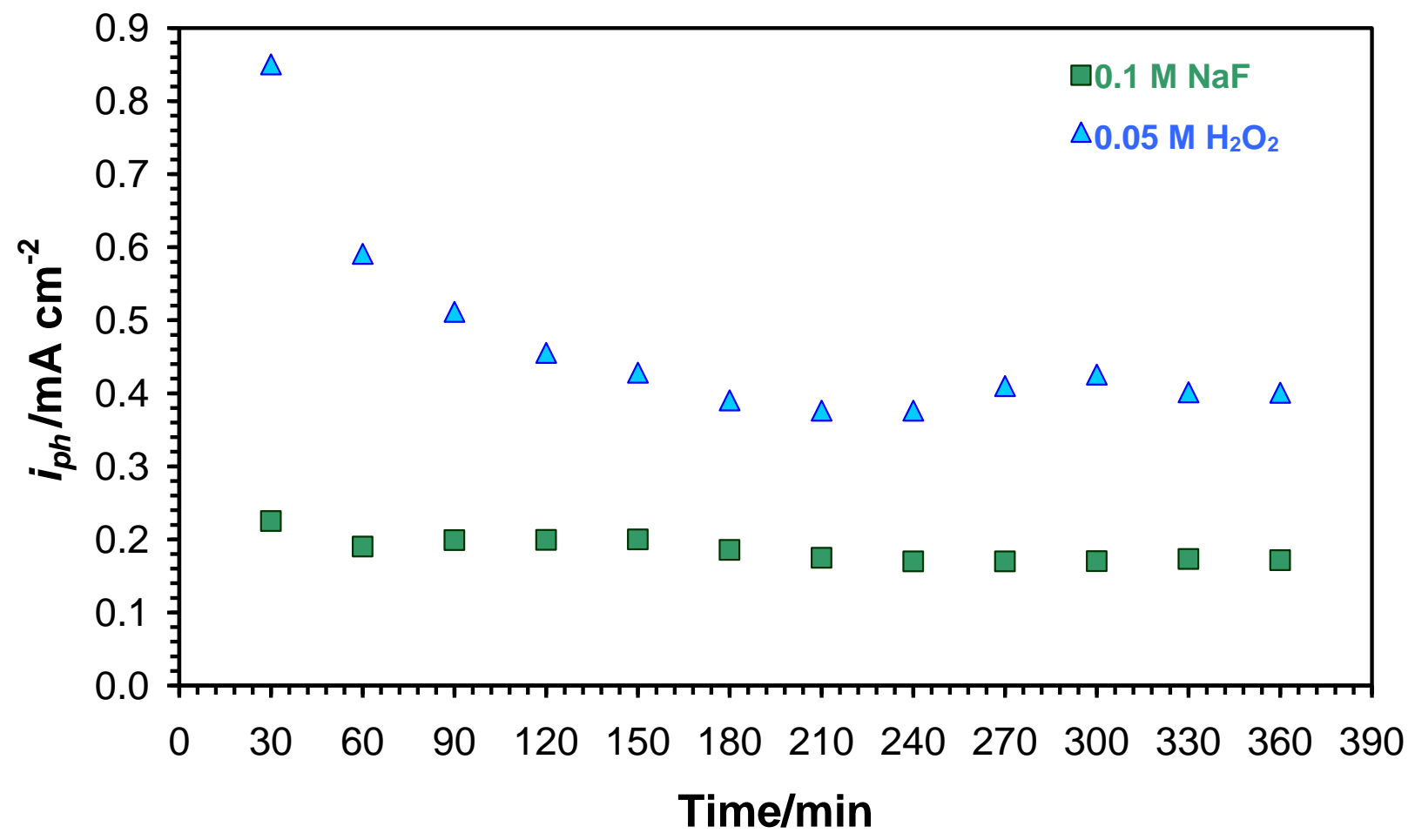

Figure 4. Evolution of photocurrent density $\left(i_{p h}\right)$ with degradation time for the two $\mathrm{WO}_{3}$ nanostructures.

It is worth mentioning that $i_{p h}$ decreased with irradiation time, especially in the nanostructure formed in the $0.05 \mathrm{M} \mathrm{H}_{2} \mathrm{O}_{2}$ solution. This decrease in photocurrent density has been reported before in the literature for $\mathrm{WO}_{3}$ photoelectrocatalysts. Several authors have associated this decrease with the formation of $\mathrm{H}_{2} \mathrm{O}_{2}$ due to incomplete water oxidation at the photoanode surface, followed by the formation of tungsten peroxo-species that are able to partially block the electrochemical active sites [52]. Nevertheless, $i_{p h}$ values reached eventually a high steady-state value, indicating that photoelectrodes were not deactivated. Therefore, the $\mathrm{WO}_{3}$ samples were photostable under the experimental degradation conditions.

The extent of the degradation reaction was followed by measuring the UV absorbance of the solution with time. Figure 5 shows the UV absorbance spectra of different 
standard solutions of diuron. Concentrations ranged from $1 \mathrm{ppm}$ to $20 \mathrm{ppm}$, and all the solutions were prepared with $0.1 \mathrm{M} \mathrm{H}_{2} \mathrm{SO}_{4}$. Two intense bands located at $211 \mathrm{~nm}$ and $247 \mathrm{~nm}$ can be observed. In general, the band used to monitor the degradation of diuron with time is the second one $(\lambda \approx 247 \mathrm{~nm})$ [53-60]. This band has been assigned to the typical $\pi \rightarrow \pi^{*}$ transition of the aromatic ring [60]. The calibration line obtained at 247 nm has also been included in the inset of Figure 5.

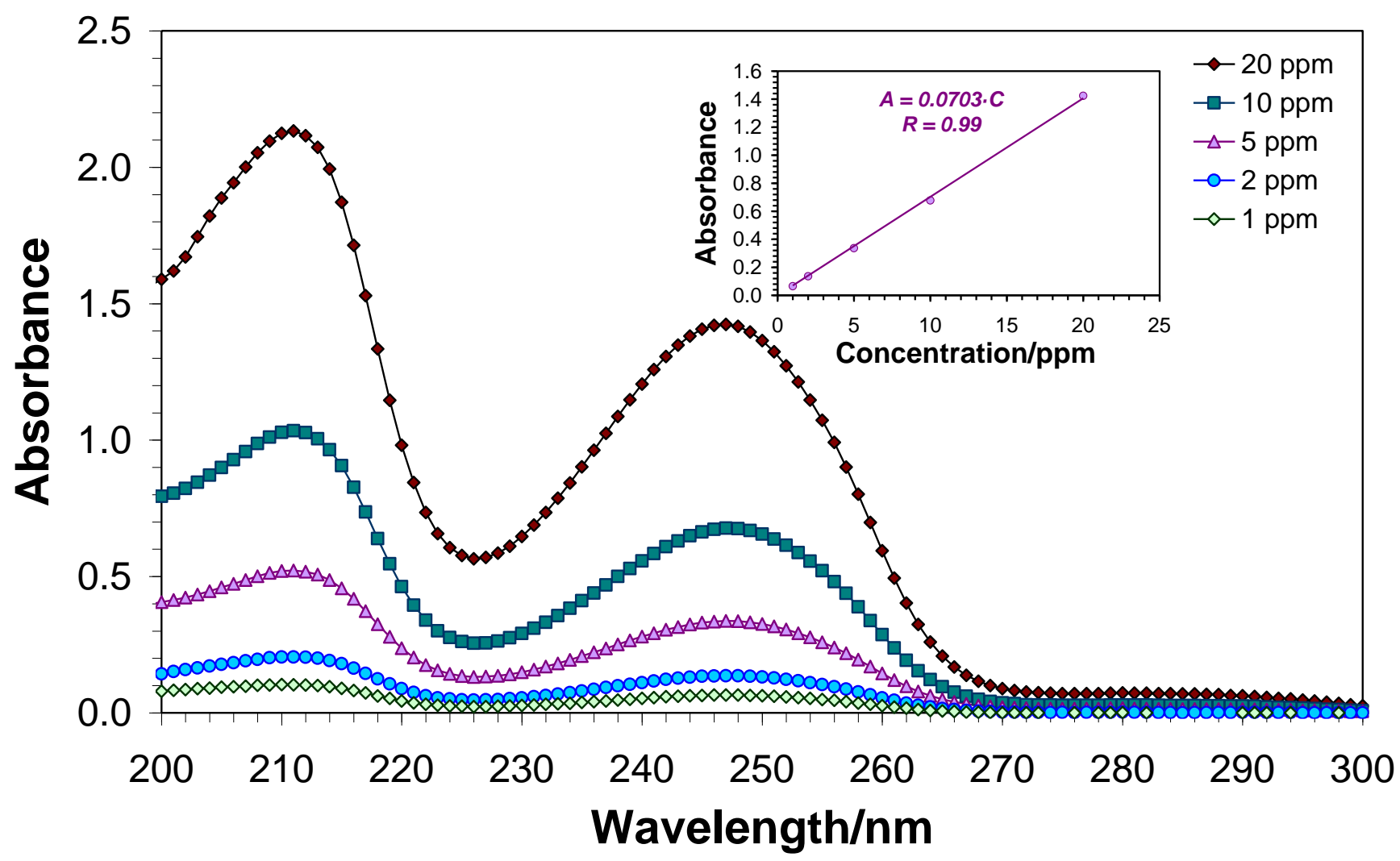

Figure 5. UV absorbance spectra of different solutions of diuron (inset: relationship obtained between absorbance $A$ and diuron concentration $C$ at a wavelength of $247 \mathrm{~nm}$ ).

The evolution of the diuron UV spectra with degradation time is shown in Figure 6 for the two $\mathrm{WO}_{3}$ nanostructures used as photoelectrocatalysts in this work. In both cases, absorbance values tended to decrease with reaction time, indicating the elimination of diuron. Neither new absorbance peaks nor displacements of the typical aromatic peak at 
$247 \mathrm{~nm}$ were detected, which may indicate that diuron degradation proceeded through the cleavage of the aromatic ring, instead of proceeding via hydroxylation and chlorine substitution. For example, Pipi et al. [59], observed the appearance of an intense absorbance peak at wavelengths of $300 \mathrm{~nm}$ after 4 hours of diuron electrolysis using DSA electrodes, which suggested the formation of a byproduct able to absorb radiation at higher wavelengths than diuron. Kovács et al. [60] observed a slight red shift upon dechlorination of the aromatic ring by gamma radiolysis (from $\lambda_{\max }=248 \mathrm{~nm}$ for diuron to $\lambda_{\max }=238 \mathrm{~nm}$ for the non-chlorinated fenuron). Hence, the reduction of the diuron absorbance peaks and the absence of new peaks or shifts in the peak at $247 \mathrm{~nm}$, indicated removal of diuron to form simple molecules [59].

It can also be observed from Figure 6 that absorbance peaks decreased significantly slower for the $\mathrm{WO}_{3}$ nanostructure synthesized in the $0.1 \mathrm{M} \mathrm{NaF}$ solution (Figure 6a) than for the one anodized in the presence of $\mathrm{H}_{2} \mathrm{O}_{2}$ (Figure 6b). Comparison between $C / C_{0}$ vs. $t$ plots for both nanostructures is displayed in Figure 7a, where $C_{0}$ is the initial diuron concentration $(20 \mathrm{ppm})$ and $C$ is diuron concentration at time $t$ obtained from absorbance $(A)$ values at $247 \mathrm{~nm}$ using the relationship shown in the inset of Figure 5. According to these results, degradation was more efficient using the $\mathrm{WO}_{3}$ nanosheets obtained in the electrolyte with hydrogen peroxide, which is consistent with the higher photocurrent densities recorded during the degradation process using that photoelectrocatalyst (see Figure 4). Degradation efficiency increased from $42 \%$ for nanoplatelets fabricated in the $0.1 \mathrm{M} \mathrm{NaF}$ solution to $73 \%$ for nanosheets fabricated in the $0.05 \mathrm{M} \mathrm{H}_{2} \mathrm{O}_{2}$ solution. 

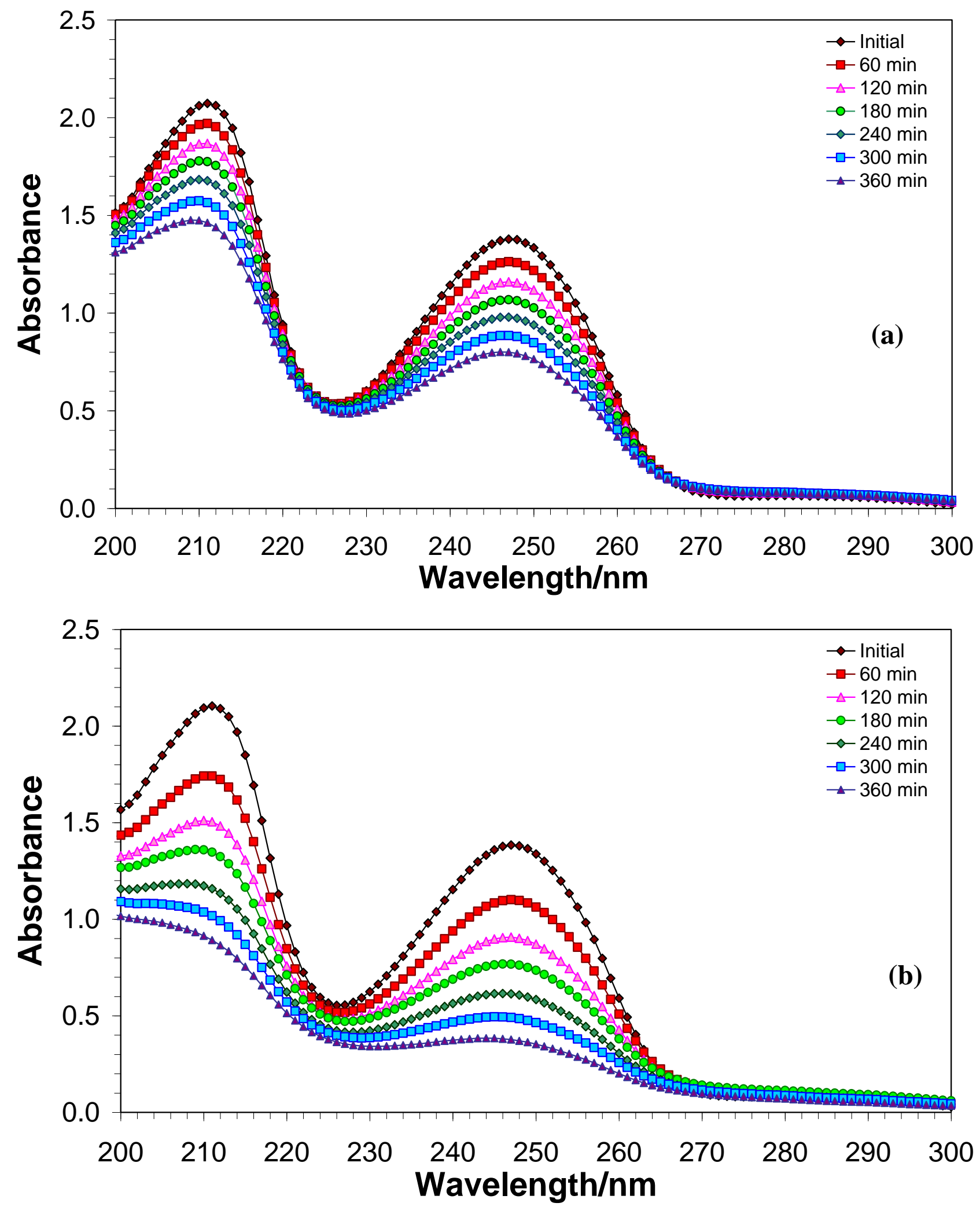

Figure 6. Evolution of the diuron UV spectra with degradation time under visible light $(420 \mathrm{~nm})$ for the $\mathrm{WO}_{3}$ nanostructures anodized in the presence of $0.1 \mathrm{M} \mathrm{NaF}$ (a) and $0.05 \mathrm{M} \mathrm{H}_{2} \mathrm{O}_{2}(\mathrm{~b})$. 


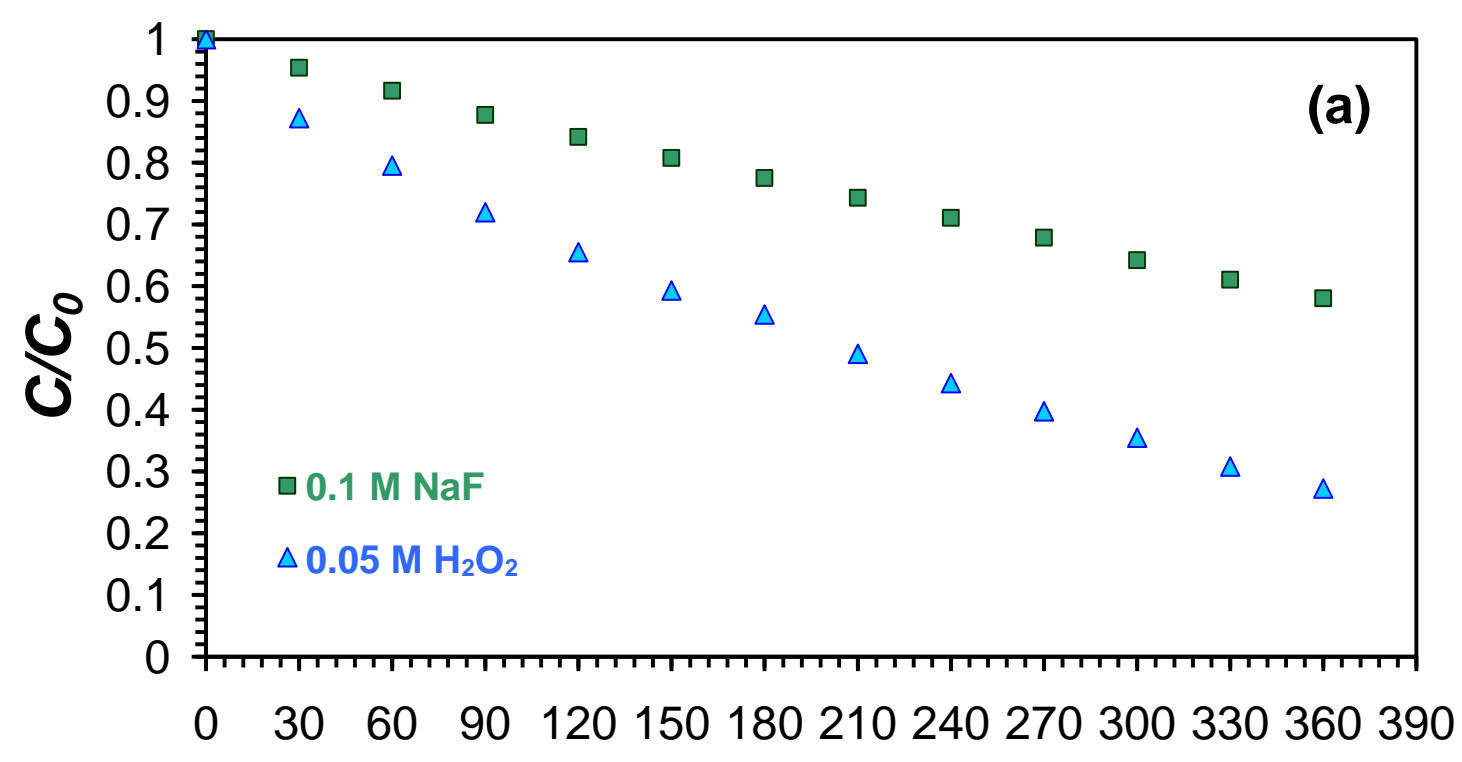

Time/min

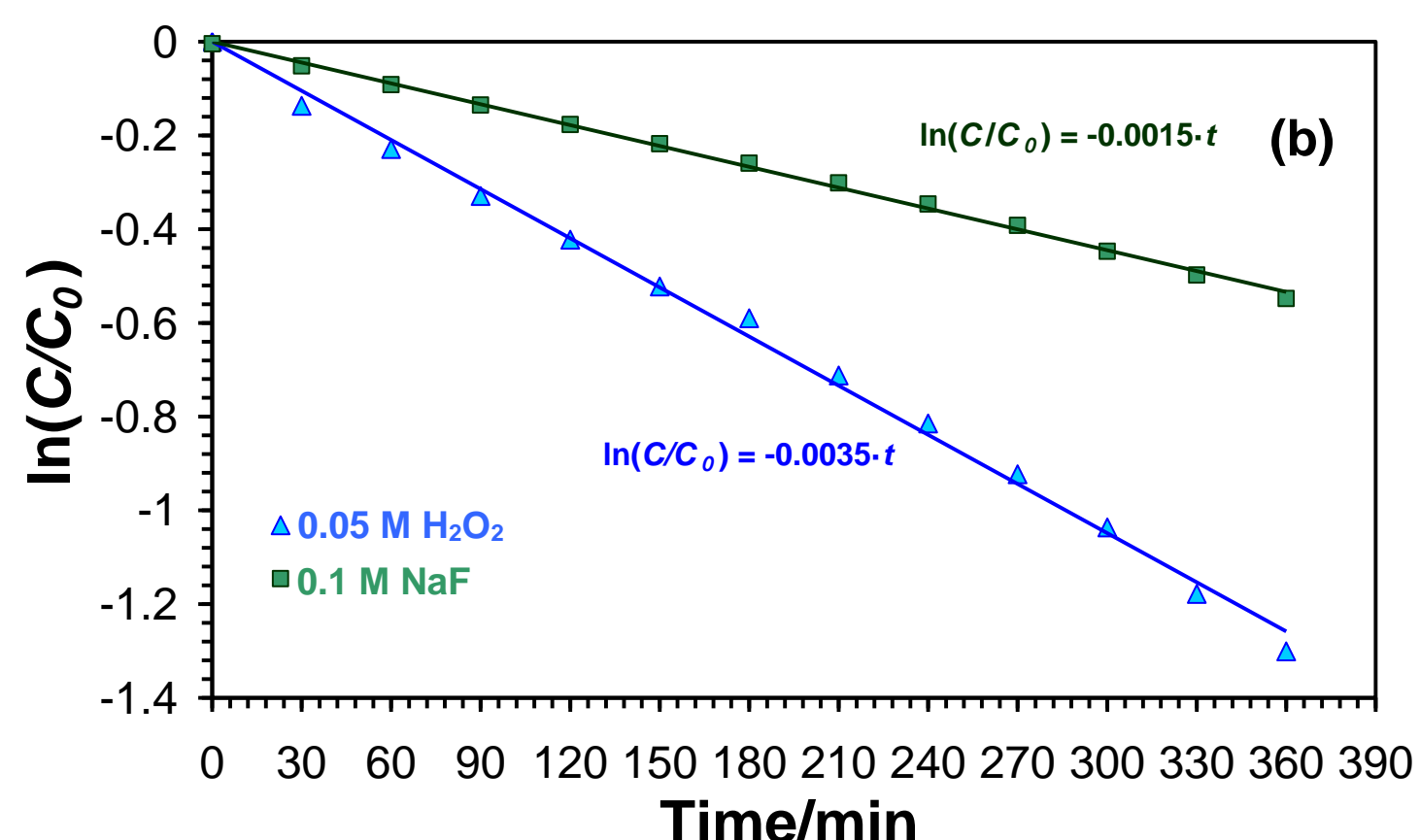

Figure 7. Diuron $C / C_{0}$ vs. time plots (a) and $\ln \left(C / C_{0}\right)$ vs. time plots (b) for the two $\mathrm{WO}_{3}$ nanostructures. 
From previous results, and assuming that the PEC degradation of diuron followed pseudo first order kinetics, the kinetic coefficient of the reaction can be determined. According to this model, a plot of $\ln \left(C / C_{0}\right)$ vs. $t$ should give a straight line from whose slope the pseudo first order kinetic coefficient, $k$, can be determined (Figure 7b). These results are shown in Table 1 for the two $\mathrm{WO}_{3}$ nanostructures, together with the coefficients of determination $R^{2}$. Values of $R^{2}$ were very close to unity, which indicates the goodness of the linear regression and the validity of the pseudo first order kinetics assumption. An increase of $133 \%$ in $k^{\prime}$ was obtained by using the $\mathrm{WO}_{3}$ nanosheets formed in the peroxide-containing electrolyte.

Table 1. Pseudo first order kinetic coefficient $k$ ' and coefficients of determination $R^{2}$ for diuron degradation using the two $\mathrm{WO}_{3}$ nanostructures.

\begin{tabular}{|c|c|c|}
\hline Anodization electrolyte & $k^{\prime} / \mathrm{h}^{-1}$ & $R^{2}$ \\
\hline $0.1 \mathrm{M} \mathrm{NaF}$ & 0.09 & 0.998 \\
\hline $0.05 \mathrm{M} \mathrm{H}_{2} \mathrm{O}_{2}$ & 0.21 & 0.996 \\
\hline
\end{tabular}

\subsection{Ionic chromatography analyses}

The concentration of $\mathrm{Cl}^{-}$and $\mathrm{NO}_{3}{ }^{-}$in the solutions after the 360 min of degradation can provide useful information on the extent of diuron mineralization. Table 2 shows the measured concentrations (in ppm) of these anions in the treated electrolyte for the two $\mathrm{WO}_{3}$ nanostructures, as well as an indication of the $\%$ of mineralization ( $\%$ miner $)$, assuming that chlorine atoms present in the diuron molecule were completely 
transformed to $\mathrm{Cl}^{-}$and nitrogen atoms to $\mathrm{NO}_{3}{ }^{-}$. Under that hypothesis, the maximum concentration of these anions would be $C_{C l-}=6.1 \mathrm{ppm}$ and $C_{N O 3_{-}}=10.6 \mathrm{ppm}$.

According to the results presented in Table 2, the maximum mineralization degree of diuron was $\sim 50 \%$, using the nanostructure synthesized in the $0.05 \mathrm{M} \mathrm{H}_{2} \mathrm{O}_{2}$ electrolyte. Notice that these values are all lower than degradation efficiencies shown in Figure 7 (after $360 \mathrm{~min}$ ), which indicates that other small molecules were formed from diuron degradation, as expected.

Table 2. Measured concentrations (in ppm) of $\mathrm{Cl}^{-}$and $\mathrm{NO}_{3}{ }^{-}$in the treated diuron electrolyte for the two $\mathrm{WO}_{3}$ nanostructures. An estimation of the $\%$ of mineralization $(\%$ miner $)$ is also shown.

\begin{tabular}{|c|c|c|c|c|}
\hline Anodization electrolyte & $C_{C l-} / \mathrm{ppm}$ & $\%_{\text {miner }}\left(\mathrm{Cl}^{-}\right)$ & $C_{\text {NO3--/ppm }}$ & $\%_{\text {miner }}\left(\mathrm{NO}_{3}{ }^{-}\right)$ \\
\hline $0.1 \mathrm{M} \mathrm{NaF}$ & 1.9 & 31.1 & 2.9 & 27.3 \\
\hline $0.05 \mathrm{M} \mathrm{H}_{2} \mathrm{O}_{2}$ & 2.9 & 47.5 & 5.5 & 51.9 \\
\hline
\end{tabular}

As it has been mentioned above, mineralization yields shown in Table 2 were determined supposing a total conversion of $\mathrm{Cl} \rightarrow \mathrm{Cl}^{-}$and $\mathrm{N} \rightarrow \mathrm{NO}_{3}^{-}$. Yet, the formation of these ions may not be complete. For example, once formed, chloride anions can be oxidized to form gaseous chlorine. On the other hand, the nitrogen in diuron can also be transformed to $\mathrm{NH}_{4}{ }^{+}$cations, apart from forming $\mathrm{NO}_{3}{ }^{-}$[61]. Therefore, values shown in Table 2 should be regarded as minimum mineralization yields. 


\section{CONCLUSIONS}

Two different $\mathrm{WO}_{3}$ nanostructures were obtained by anodization of tungsten in two electrolytes: $1.5 \mathrm{M} \mathrm{H}_{2} \mathrm{SO}_{4}+0.1 \mathrm{M} \mathrm{NaF}$ and $1.5 \mathrm{M} \mathrm{H}_{2} \mathrm{SO}_{4}+0.05 \mathrm{M} \mathrm{H}_{2} \mathrm{O}_{2}$. Nanoplatelets/nanosheets were obtained in both cases, but the dimensions of the nanostructures synthesized in the latter electrolyte were significantly lower due to the interactions between tungsten species and hydrogen peroxide.

Photocurrent densities obtained during visible-light diuron degradation were noticeably higher for the nanostructures fabricated in the peroxide-containing solution. This result arose from the higher electrocatalytic activity (higher surface area) of these nanosheets compared with the ones formed in the $\mathrm{F}^{-}$-containing electrolyte.

The evolution of diuron absorbance peaks during degradation time indicated removal of the pesticide to form simple molecules, probably through the cleavage of the aromatic ring.

Diuron absorbance peaks decreased significantly faster for the $\mathrm{WO}_{3}$ nanostructure synthesized in the $0.05 \mathrm{M} \mathrm{H}_{2} \mathrm{O}_{2}$ solution than for the one anodized in the presence of $\mathrm{F}^{-}$, which was consistent with the measured photocurrent densities. In fact, the pseudo first order kinetic coefficient for the former nanostructure was $133 \%$ higher than for the latter. 
A degradation efficiency of $73 \%$ and a minimum mineralization degree of $50 \%$ were obtained for the nanostructure synthesized in the $0.05 \mathrm{M} \mathrm{H}_{2} \mathrm{O}_{2}$ electrolyte after $360 \mathrm{~min}$ of visible illumination.

\section{Acknowledgements}

Authors thank for the financial support to the Ministerio de Economía y Competitividad (Project Code: CTQ2016-79203-R) and for the co-finance by the European Social Fund.

\section{REFERENCES}

[1] H. Zhang, G. Chen, D. W. Bahnemann. Photoelectrocatalytic materials for environmental applications, J. Mater. Chem. 19 (2009) 5089-5121.

[2] R. Daghrir, P. Drogui, D. Robert. Photoelectrocatalytic technologies for environmental applications, J. Photoch. Photobio. A 238 (2012) 41-52.

[3] G. Garcia Bessegato, T. Tasso Guaraldo, M. V. Boldrin Zanoni, Enhancement of Photoelectrocatalysis Efficiency by Using Nanostructured Electrodes, in: M. Aliofkhazraei (ed.), Modern Electrochemical Methods in Nano, Surface and Corrosion Science. InTech, London, 2014, pp. 271-319.

[4] S. Garcia-Segura, E. Brillas. Applied photoelectrocatalysis on the degradation of organic pollutants in wastewaters, J. Photoch. Photobio. C 31 (2017) 1-35.

[5] L.J. Minggu, W.R.W. Daud, M.B. Kassim, An overview of photocells and photoreactors for photoelectrochemical water splitting, Int. J. Hydrogen Energ. 35 (2010) 5233-5244.

[6] R. van de Krol, Principles of Photoelectrochemical Cells, in: R. van de Krol, M. Grätzel (eds.), Photoelectrochemical Hydrogen Production, New York, 2012.

[7] G.G. Bessegato, T.T. Guaraldo, J.F. de Brito, M.F. Brugnera, M.V.B. Zanoni, Achievements and Trends in Photoelectrocatalysis: from Environmental to Energy Applications, Electrocatal. 6 (2015) 415-441.

[8] Q. Zheng, J. Bai, J. Li, L. Li, L. Xia, B. Zhou, Y. Sun, Highly-stable and efficient photocatalytic fuel cell based on an epitaxial $\mathrm{TiO}_{2} / \mathrm{WO}_{3} / \mathrm{W}$ nanothorn photoanode and enhanced radical reactions for simultaneous electricity production and wastewater treatment, Appl. Energ. 220 (2018) 127-137. 
[9] A. Eftekhari, V. J. Babu, S. Ramakrishna. Photoelectrode nanomaterials for photoelectrochemical water splitting, Int. J. Hydrogen Energ. 42 (2017) 1107811109.

[10] H. Zheng, J. Z. Ou, M. S. Strano, R. B. Kaner, A. Mitchell, K. Kalantar-zadeh. Nanostructured Tungsten Oxide - Properties, Synthesis, and Applications, Adv. Funct. Mater. 21 (2011) 2175-2196.

[11] J. Luo, M. Hepel. Photoelectrochemical degradation of naphthol blue black diazo dye on $\mathrm{WO}_{3}$ film electrode, Electrochim. Acta 46 (2001) 2913-2922.

[12] R. Solarska, C. Santato, C. Jorand-Sartoretti, M. Ulmann, J. Augustynski. Photoelectrolytic oxidation of organic species at mesoporous tungsten trioxide film electrodes under visible light illumination, J. Appl. Electrochem. 35 (2005) 715-721.

[13] L. E. Fraga, M. V. Zanoni. Nanoporous of $\mathrm{W} / \mathrm{WO}_{3}$ Thin Film Electrode Grown by Electrochemical Anodization Applied in the Photoelectrocatalytic Oxidation of the Basic Red 51 used in Hair Dye, J. Braz. Chem. Soc. 22 (2011) 718-725.

[14] Q. Zheng, C. Lee. Visible light photoelectrocatalytic degradation of methyl orange using anodized nanoporous $\mathrm{WO}_{3}$, Electrochim. Acta 115 (2014) 140145.

[15] S. S. Thind, K. Rozic, F. Amano, A. Chen. Fabrication and photoelectrochemical study of $\mathrm{WO}_{3}$-based bifunctional electrodes for environmental applications, Appl. Catal. B Environ 176-177 (2015) 464-471.

[16] Y. M. Hunge, V. S. Mohite, S. S. Kumbhar, K. Y. Rajpure, A. V. Moholkar, C. $\mathrm{H}$. Bhosale. Photoelectrocatalytic degradation of methyl red using sprayed $\mathrm{WO}_{3}$ thin films under visible light irradiation, J. Mater. Sci.: Mater. Electron. 26 (2015) 8404-8412.

[17] S. V. Mohite, V. V. Ganbavle, K. Y. Rajpure. Solar photoelectrocatalytic activities of rhodamine-B using sprayed $\mathrm{WO}_{3}$ photoelectrode, J. Alloy. Compd. 655 (2016) 106-113.

[18] Y. M. Hunge, M. A. Mahadik, S. S. Kumbhar, V. S. Mohite, K. Y. Rajpure, N. G. Deshpande, A. V. Moholkar, C. H. Bhosale. Visible light catalysis of methyl orange using nanostructured $\mathrm{WO}_{3}$ thin films, Ceram. Int. 42 (2016) 789-798.

[19] J. Zheng, J. Li, J. Bai, X. Tan, Q. Zeng, L. Li, B. Zhou. Efficient Degradation of Refractory Organics Using Sulfate Radicals Generated Directly from $\mathrm{WO}_{3}$ Photoelectrode and the Catalytic Reaction of Sulfate, Catalysts 7 (2017) 346.

[20] S. V. Mohite, V. V. Ganbavle, K. Y. Rajpure. Photoelectrocatalytic activity of immobilized $\mathrm{Yb}$ doped $\mathrm{WO}_{3}$ photocatalyst for degradation of methyl orange dye, J. Energy Chem. 26 (2017) 440-447. 
[21] R. M. Fernández-Domene, R. Sánchez-Tovar, B. Lucas-Granados, C. S. GarcíaZamora, J. García-Antón. Customized $\mathrm{WO}_{3}$ nanoplatelets as visible-light photoelectrocatalyst for the degradation of a recalcitrant model organic compound (methyl orange), J. Photochem. Photobiol. A: Chem. 356 (2018) 4656.

[22] E. O. Scott-Emuakpor, A. Kruth, M. J. Todd, A. Raab, G. I. Paton, D. E. Macphee. Remediation of 2,4-dichlorophenol contaminated water by visible light-enhanced $\mathrm{WO}_{3}$ photoelectrocatalysis, Appl. Catal. B: Environ. 123-124 (2012) 433-439.

[23] S. S. Thind, M. Tian, A. Chen. Direct growth and photo-electrochemical study of $\mathrm{WO}_{3}$ nanostructured materials, Electrochem. Commun. 43 (2014) 13-17.

[24] S. Xie, K. Ouyang. Degradation of refractory organic compounds by photocatalytic fuel cell with solar responsive $\mathrm{WO}_{3} / \mathrm{FTO}$ photoanode and airbreathing cathode, J. Colloid Interf. Sci. 500 (2017) 220-227.

[25] G. Longobucco, L. Pasti, A. Molinari, N. Marchetti, S. Caramori, V. Cristino, R. Boaretto, C. A. Bignozzi. Photoelectrochemical mineralization of emerging contaminants at porous $\mathrm{WO}_{3}$ interfaces, Appl. Catal. B: Environ. 204 (2017) 273-282.

[26] S. V. Mohite, V. V. Ganbavle, K. Y. Rajpure. Photoelectrochemical performance and photoelectrocatalytic degradation of organic compounds using $\mathrm{Ga}: \mathrm{WO}_{3}$ thin films, J. Photochem. Photobiol. A: Chem. 344 (2017) 56-63.

[27] Q. Zeng, J. Li, L. Li, J. Bai, L. Xia, B. Zhou. Synthesis of $\mathrm{WO}_{3} / \mathrm{BiVO}_{4}$ photoanode using a reaction of bismuth nitrate with peroxovanadate on $\mathrm{WO}_{3}$ film for efficient photoelectrocatalytic water splitting and organic pollutant degradation, Appl. Catal. B: Environ. 217 (2017) 21-29.

[28] Diuron Information - European Chemicals Agency (ECHA) (https://echa.europa.eu/substance-information/-/substanceinfo/100.005.778).

(Accessed 8 May 2018).

[29] Environmental Risk Assessment for the Reregistration of Diuron - United States Environmental Protection Agency (EPA), 2001.

[30] F. Akcha, A. Barranger, E. Bachère, C. H. Berthelin, D. Piquemal, P. Alonso, R. R. Sallan, G. Dimastrogiovanni, C. Porte, D. Menard, A. Szczybelski, A. Benabdelmouna, M. Auffret, J. Rouxel, T. Burgeot. Effects of an environmentally relevant concentration of diuron on oyster genitors during gametogenesis: responses of early molecular and cellular markers and physiological impacts, Environ. Sci. Pollut. Res. 23 (2016) 8008-8020.

[31] T. S. Boscolo Pereira, C. N. Pereira Boscolo, A. A. Felício, S. R. Batlouni, D. Schlenk, E. ves de Almeida. Estrogenic activities of diuron metabolites in female Nile tilapia (Oreochromis niloticus), Chemosphere 146 (2016) 497-502. 
[32] M. Velki, C. Di Paolo, J. Nelles, T. B. Seiler, H. Hollert. Diuron and diazinon alter the behavior of zebrafish embryos and larvae in the absence of acute toxicity, Chemosphere 180 (2017) 65-76.

[33] M. R. M. Khanam, Y. Shimasaki, M. Z. Hosain, K. Mukai, M. Tsuyama, X. Qiu, R. Tasmin, H. Goto, Y. Oshima. Diuron causes sinking retardation and physiochemical alteration in marine diatoms Thalassiosira pseudonana and Skeletonema marinoi-dohrnii complex, Chemosphere 175 (2017) 200-209.

[34] S. Hasenbein, J. Peralta, S. P. Lawler, R. E. Connon. Environmentally relevant concentrations of herbicides impact non-target species at multiple sublethal endpoints, Sci. Total Environ. 607-608 (2017) 733-743.

[35] D. J. Rowen, M. A. Templeman, M. J. Kingsford. Herbicide effects on the growth and photosynthetic efficiency of Cassiopea maremetens, Chemosphere 182 (2017) 143-148.

[36] C. N. P. Boscolo, T. S. B. Pereira, I. G. Batalhão, P. L. R. Dourado, D. Schlenk, E. A. de Almeida. Diuron metabolites act as endocrine disruptors and alter aggressive behavior in Nile tilapia (Oreochromis niloticus), Chemosphere 191 (2018) 832-838.

[37] S. Beernaerts, M. Gerard, P. Debongnie, J. P. Barthelemy, L. Pussemier, A. Copin. Two Years of Pesticides Monitoring in a Belgian Watershed, Int. J. Environ. An. Ch. 83 (2003) 469-480.

[38] R. Loos, R. Carvalho, D. C. António, S. Comero, G. Locoro, S. Tavazzi, B. Paracchini, M. Ghiani, T. Lettieri, L. Blaha, B. Jarosova, S. Voorspoels, K. Servaes, P. Haglund, J. Fick, R. H. Lindberg, D. Schwesig, B. M. Gawlik. EUwide monitoring survey on emerging polar organic contaminants in wastewater treatment plant effluents, Water Res. 47 (2013) 6475-6487.

[39] T. D. H. Le, A. Scharmüller, M. Kattwinkel, R. Kühne, G. Schüürmann, R. B. Schäfer. Contribution of waste water treatment plants to pesticide toxicity in agriculture catchments, Ecotox. Environ. Safe. 145 (2017) 135-141.

[40] Z. Tousova, P. Oswald, J. Slobodnik, L. Blaha, M. Muz, M. Hu, W. Brack, M. Krauss, C. Di Paolo, Z. Tarcai, T. B. Seiler, H. Hollert, S. Koprivica, M. Ahel, J. E. Schollée, J. Hollender, M. J. F. Suter, A. O. Hidasi, K. Schirmer, M. Sonavane, S. it-Aissa, N. Creusot, F. Brion, J. Froment, A. C. Almeida, K. Thomas, K. E. Tollefsen, S. Tufi, X. Ouyang, P. Leonards, M. Lamoree, V. O. Torrens, A. Kolkman, M. Schriks, P. Spirhanzlova, A. Tindall, T. Schulze. European demonstration program on the effect-based and chemical identification and monitoring of organic pollutants in European surface waters, Sci. Total Environ. 601-602 (2017) 1849-1868.

[41] J. Yuan, M. I. Van Dyke, P. M. Huck. Identification of critical contaminants in wastewater effluent for managed aquifer recharge, Chemosphere 172 (2017) 294-301. 
[42] H. Chen, Y. Luo, C. Potter, P. J. Moran, M. L. Grieneisen, M. Zhang. Modeling pesticide diuron loading from the San Joaquin watershed into the SacramentoSan Joaquin Delta using SWAT, Water Res. 121 (2017) 374-385.

[43] B. Reoyo-Prats, D. Aubert, C. Menniti, W. Ludwig, J. Sola, M. Pujo-Pay, P. Conan, O. Verneau, C. Palacios. Multicontamination phenomena occur more often than expected in Mediterranean coastal watercourses: Study case of the Têt River (France), Sci. Total Environ. 579 (2017) 10-21.

[44] M. A. Rippy, A. Deletic, J. Black, R. Aryal, J. L. Lampard, J. Y.-M. Tang, D. McCarthy, P. Kolotelo, J. Sidhu, W. Gernjak. Pesticide occurrence and spatiotemporal variability in urban run-off across Australia, Water Res. 115 (2017) 245-255.

[45] N. A. Munz, F. J. Burdon, D. de Zwart, M. Junghans, L. Melo, M. Reyes, U. Schönenberger, H. P. Singer, B. Spycher, J. Hollender, C. Stamm. Pesticides drive risk of micropollutants in wastewater-impacted streams during low flow conditions, Water Res. 110 (2017) 366-377.

[46] R. Münze, C. Hannemann, P. Orlinskiy, R. Gunold, A. Paschke, K. Foit, J. Becker, O. Kaske, E. Paulsson, M. Peterson, H. Jernstedt, J. Kreuger, G. Schüürmann, M. Liess. Pesticides from wastewater treatment plant effluents affect invertebrate communities, Sci. Total Environ. 599-600 (2017) 387-399.

[46] L. Le Coadou, K. Le Ménach, P. Labadie, M. H. Dévier, P. Pardon, S. Augagneur, H. Budzinski. Quality survey of natural mineral water and spring water sold in France: Monitoring of hormones, pharmaceuticals, pesticides, perfluoroalkyl substances, phthalates, and alkylphenols at the ultra-trace level, Sci. Total Environ. 603-604 (2017) 651-662.

[48] E. Herrero-Hernández, M. S. Rodríguez-Cruz, E. Pose-Juan, S. SánchezGonzález, M. S. Andrades, M. J. Sánchez-Martín. Seasonal distribution of herbicide and insecticide residues in the water resources of the vineyard region of La Rioja (Spain), Sci. Total Environ. 609 (2017) 161-171.

[49] L. H. Nowell, P. W. Moran, T. S. Schmidt, J. E. Norman, N. Nakagaki, M. E. Shoda, B. J. Mahler, P. C. Van Metre, W. W. Stone, M. W. Sandstrom, M. L. Hladik. Complex mixtures of dissolved pesticides show potential aquatic toxicity in a synoptic study of Midwestern U.S. streams, Sci. Total Environ. 613-614 (2018) 1469-1488.

[50] R. M. Fernández-Domene, R. Sánchez-Tovar, B. Lucas-Granados, G. RosellóMárquez, J. García-Antón. A simple method to fabricate high-performance nanostructured $\mathrm{WO}_{3}$ photocatalysts with adjusted morphology in the presence of complexing agents, Mater. Design 116 (2017) 160-170.

[51] E. Lassner and W. D. Schubert, Tungsten. Properties, Chemistry, Technology of the Element, Alloys, and Chemical Compounds, Kluwer Academic / Plenum Publishers, New York, 1999. 
[52] J. A. Seabold, K. S. Choi. Effect of a Cobalt-Based Oxygen Evolution Catalyst on the Stability and the Selectivity of Photo-Oxidation Reactions of a $\mathrm{WO}_{3}$ Photoanode, Chem. Mater. 23 (2011) 1105-1112.

[53] M. Van Boven, L. Laruelle, P. Daenens. HPLC Analysis of Diuron and Metabolites in Blood and Urine, J. Anal. Toxicol. 14 (1990) 231-234.

[54] P. Mazellier, J. Jirkovsky, M. Bolte. Degradation of Diuron Photoinduced by Iron(III) in Aqueous Solution, Pestic. Sci. 49 (1997) 259-267.

[55] J. Jirkovský, V. Faure, P. Boule. Photolysis of Diuron, Pestic. Sci. 50 (1999) 4252.

[56] K. Djebbar, T. Sehili, P. Mazellier, J. De Laat. Phototransformation of diuron in aqueous solution by UV irradiation in the absence and in the presence of $\mathrm{H}_{2} \mathrm{O}_{2}$, Environ. Technol. 24 (2003) 479-489.

[57] M. J. Farré, M. I. Maldonado, W. Gernjak, I. Oller, S. Malato, X. Domènech, J. Peral. Coupled solar photo-Fenton and biological treatment for the degradation of diuron and linuron herbicides at pilot scale, Chemosphere 72 (2008) 622-629.

[58] F. Galindo-Hernández, J. A. Wang, R. Gómez, X. Bokhimi, L. Lartundo, A. Mantilla. Structural modifications in $\mathrm{Au} / \mathrm{Al}_{2} \mathrm{O}_{3}-\mathrm{CeO}_{2}$ mixed oxides as a function of $\mathrm{Ce}^{4+}$ content and its effects in the mineralization of the herbicide diuron, $\mathrm{J}$. Photochem. Photobiol. A: Chem. 243 (2012) 23-32.

[59] A. R. F. Pipi, S. A. Neto, A. R. De Andrade. Electrochemical Degradation of Diuron in Chloride Medium using DSA® Based Anodes, J. Braz. Chem. Soc. 24 (2013) 1259-1266.

[60] K. Kovács, S. He, V. Mile, T. Csay, E. Takács, L. Wojnárovits. Ionizing radiation induced degradation of diuron in dilute aqueous solution, Chem. Cent. J. 9 (2015) 21.

[61] D. Bamba, P. Atheba, D. Robert, A. Trokourey, B. Dongui. Photocatalytic degradation of the diuron pesticide, Environ. Chem. Lett. 6 (2008) 163-167. 